\title{
E-Learning-Based Trainings for Expenditure Treasurers
}

\author{
Rahmawati $^{1}$ and Mila Mumpuni ${ }^{2}$ \\ ${ }^{1}$ A Lecturer at economics Faculty Sebelas Maret University Surakarta \\ ${ }^{2} \mathrm{~A}$ Trainer at the Finance Education and Training Center \\ E-mail:1'grahmaw2005@yahoo.com,2edelweis36@yahoo.com
}

\begin{abstract}
The fulfillment of the functional personnel as Expenditure Treasurers becomes the target of not only central government offices but also local government offices. The legal foundation of the reform of the government's financial management making a treasurer a functional position opens an opportunity for the development of a civil servant's career. The pattern of trainings for expenditure treasurers in education and training centers is still oriented to classroom learning. The target of fulfilling functional personnel through training in terms of quantity and quality has to be attained immediately. The development of information technology in the field of education makes information-technology-based training patterns possible. An elearning model can become a form of training for treasures in the future. The advantages of e-learning serve as an attempt to minimize the pattern that has been applied in the training so far. E-learning can be only a dream if there is no willingness on the part of the participants, instructors, and education and training institutions to change the training pattern. However, it can be the best solution in the future as an efficient and effective training pattern.
\end{abstract}

Keywords: Education and Training, Expenditure Treasurer, E-learning.

\section{INTRODUCTION}

According to Act Number 17 Year 2003 Article 35 Clause 2, a treasurer is a person whose duties are to accept, keep, pay and/or give money or bonds or the government's belongings. Further, UUKN Article 35 Clause 3 states that it is obligatory for a treasurer to personally responsible for the government's loss under his or her management. It means that a treasurer is required to think, show attitudes, and behave professionally in terms of the functional duties he or she has to perform and consequently personally he or she must be responsible for the violation under his or her management.

We know that the holders of people's mandate in the management of the government's/region's finance are the budget users and the government's/region's general treasurers. However, the performance that must be directly accounted for by Badan Pemeriksa Keuangan (the Finance Supervising Body) is that of the treasurer as an individual. A treasurer's performance itself can result from the performance of the budget users.
This is the unique or outstanding characteristic of a treasurer's function. In accordance with the mandate stated in Act Number 1 Year 2004 regarding the Government's Treasury (UUPN) Article 10, both the revenue treasurer and the expenditure treasurer are functional officials.

Consequently, a functional official is responsible not only for the main duties and functions but also for the personal matters. Therefore, a treasurer is required to show professional attitudes and behaviors and to be proportional in managing the government's/region's finance. In other words, a treasurer is an important component in the management of the government's finance besides the Budget User Authority, Commitent Making Official, and SPM Issuing Official. In the local government, the Expenditure Treasurer is regulated by Regulations by the Minister of Domestic Affairs Number 55 Year 2008 regarding the accountability reporting as the Expenditure Treasurer. The regulations aim to make a harmonious process in the central and local governments.

The fulfillment of personnel as Expenditure Treasurers has been done through trainings and has 
not become a career development for civil servants because of the low motivation to join trainings. Besides motivation, the training pattern limited to time and space makes training participants find it difficult to adopt knowledge and skills as Expenditure Treasurers. This implies that information technology has not been used as a learning facility by prospective expenditure treasurers

\section{TRAINING}

A work unit in each regency/municipality is obligated to be managed by one expenditure treasurer. This management is intended to deal with the appearance of Dokumen Pengelolaan Anggaran (or Budget Management Document) or DPA, for short. It means that each DPA is managed by one expenditure treasurer. Therefore, to ensure sufficient availability of expenditure treasurers after the oncoming legalization of treasurers as functional officials, there need to be a number of new treasurers fulfilling the standard of competence required.

The standard of competence needs to be acquired through an effective and efficient learning process. The ongoing education and training programs mostly use the conventional learning model, namely, that with the learning process taking place in the classroom, featuring face-to-face processes, and involving direct interactions between the instructors and the participants of the education and training programs. Such a conventional learning model is also locally called Model Tatap Muka (or Face-To-Face Model) in university circles (Depdiknas, 2007: 49-50), with the learning activities done in direct meetings between lecturers and students within time lengths according to students' choice: full class periods or half class periods. Generally, in sessions using that model the interactions between the participants of the education and training programs and their instructors/facilitators/teachers could lead to the creation of such interactive activities as participants' note-taking and listening activities, class discusions in the form of questions- andanswers forums, and even exercises or drills and practice as well as competence evaluation.

The model that has been applied on most education and training programs is not yet sufficiently effective because it has a time constraint. The time implied here is that which the participants and teachers should spare. In the course of being assigned to participate in the education and training programs, the participants have to abandon their main jobs at their institutions of origin. The next constraint is that when the participants return to their institutions of origin, they undergo an internal mutation process which results in their inability to implement the results of their education and training programs. It results in a vacancy of functional staff at some governmental institutions and, on the other hand, there occurs an accummulation of functional staff at some other governmental institutions.

Time acts as hindrance to the teachers who do not have the status of widyaswaras, who are pegawai negeri sipils (or civil servants, i.e., state-employed civilians) or PNS, for short, who are appointed as functional officials to educate, teach, and/or train other PNS at governmental education and training institutions. The limited number of widyaiswaras who have competence in the accounting field results in the forced involvement of structural officials. Unfortunately, the main job as structural official sometimes disturbs the learning process in class when there is a sudden assignment as structural official. Providing reserve teachers becomes a difficult matter for the program organizers when the replacement is sudden in nature at the time the learning process is in progress.

Time also acts as hindrance for the learning process because its being restricted to the classroom makes it become a burden for both the participants and the teachers of the education and training programs concerned. The program organizers demand the participants' capability of understanding and implementing the materials by the end of the programs even when the participants know nothing at all about the materials at the beginning. They likewise demand the teachers' capability of making even participants who know nothing about the materials at the beginning capable of understanding and implementing them at the end.

DVD use becomes the first part of the development of the new learning model. Its purpose is to make a change in the learning method so that it becomes one which is centered on the participants of the education and training programs through DVD materials. Besides, the process of the interaction between the participants of the education and training programs and their teachers is to be done by means of online tutorial, making it an e-learning process, so that when geographical conditions make online interaction impossible, independent learning through DVD use becomes a main point. The process by either DVD or elearning is implemented in the course of developing the participants' cognitive aspect. The development 
of the psychomotor aspect is done through the faceto-face learning process in the classrooms provided.

\section{E-LEARNING}

E-learning (Romi SW, 2007) is: 1) a new learning method using computer network media and the internet and 2) the delivery of learning materials (contents) through electronic media so that the delivered learning materials are in the electronic (digital) form. According to Wong (2008: 147), e-learning uses computer- or websitebased information and communication technology for learning.

The learning model which would be developed here involves participants who have, as part of their entry behavior and competence, a responsibility in the financial field at their respective governmental institutions. The learning process involves teachers/instructors who are competent in the field of making financial reports. The learning model requires the availability of an accurate guideline to the education and training program concerned so that at the time the program is in operation, it runs as hoped.

In scope, the guideline of the education and training program covers the following points, among others, (1) a structured education and training curriculum and its materials; (2) participants and teachers; (3) facilities and resources; and (4) learning evaluation. The guideline could be well implemented with the involvement of supportive learning media and effective learning schedules. The end product of this learning model is evaluated by administering a learning evaluation to the participants and administering an evaluation of the implementation process to the participants, teachers, and other education and training staff with reference to DVD use, e-learning, and face-to-face learning.

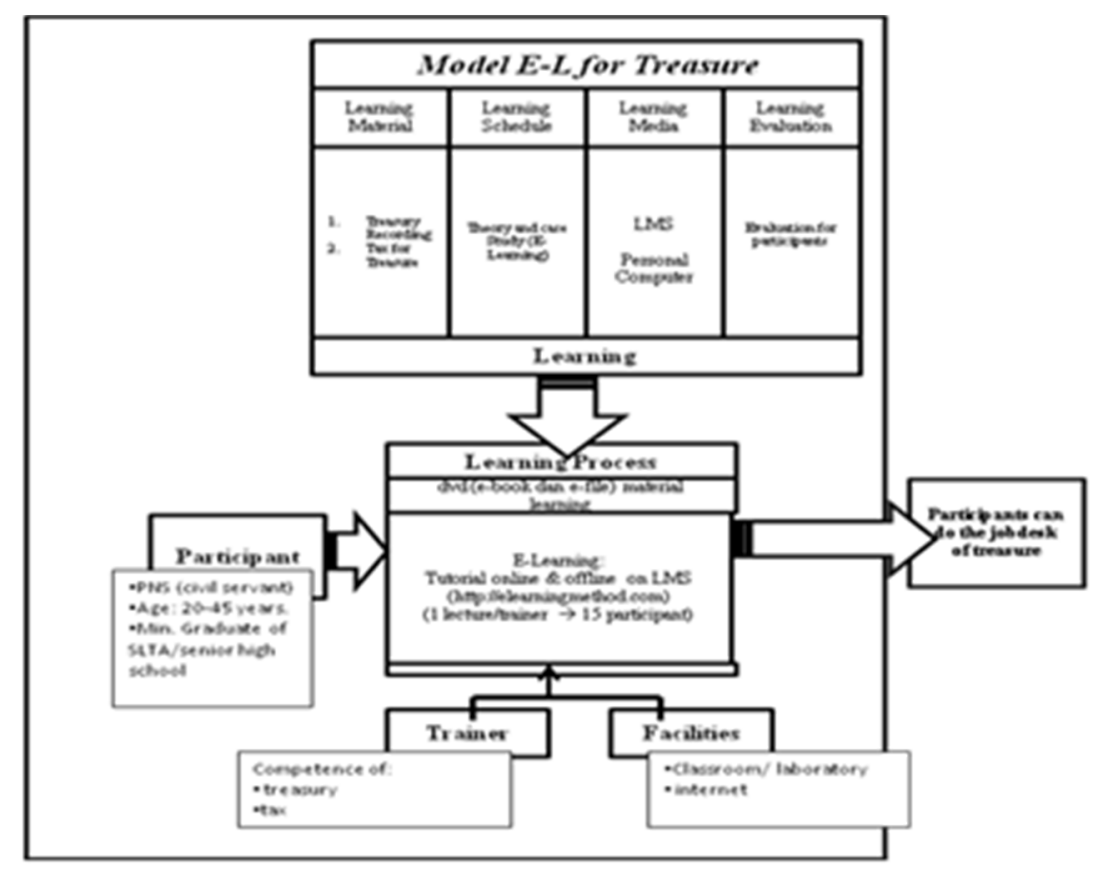

Fig. 1. Model for E-L Treasure

\section{1) Curriculum}

The first step in curriculum construction here is determining the standard of technical competence which one requires as regional/municipal government treasurer. The next step is composing a scoring rubric. With the availability of the scoring rubric, then the target of the treasurer competence formation could be actualized. Here the scoring rubric is to be the basis for the learning model curriculum coverage to provide the cognitive aspect with $60 \%$ of weight, the affective aspect with $16 \%$ of weight, and the psychomotor aspect with the remaining $24 \%$ of weight.

\section{2) Participant}

The education and training program participants here should fulfill the criterion of being PNS (civel servant) who meet the following requirements: 
a) graduating, at the minimum, from sekolah lanjutan tingkat atas (or senior high school) or SLTA, for short, or equivalent educational institutions, b) being at least 20 years and at most 45 years of age, c) having the position of at least Pengatur Muda and the rank of at least II/a, d) having an access to the Internet (at least one that their institutions of origin could provide them with), e) possessing a laptop with a screen size of 12 " at the minimum, f) having an e-mail address, and g) being given priority if possessing responsibility in the field of finance and/or equipment.

\section{3) Teacher}

The competence which the teachers should possess consists of the following: a) indicating a commitment to teaching by expressing readiness to sign a pact of integrity, b) being competent in the treasury field, c) being competent in taxation, d) having an e-mail address, and e) having a fondness for information technology.

\section{4) Material}

The materials which are applied on the model concerned here cover knowledge concerning expenditure treasurer bookkeeping and the taxation which is under the management of an expenditure treasurer.

\section{5) Method \\ i. $\quad$ Independent Learning By DVD}

The independent learning in the model concerned here uses materials in DVD. Here the learning relies fully on participants' understanding of the knowledge originating in the DVD materials. Participants could use the DVD materials without being restricted by space and time, which are fully left to the participants' choice. The method of using DVD here has the purpose of enabling the source of knowledge to be used by anybody anytime because the materials are in a form which is more flexible than printed form.

\section{ii. $\quad$ E-Learning}

The learning model applies the e-learning method by means of questions-and-answers sessions using the Forum facility, online discussions using the Chatting facility, or materials or assignments in the format of a learning management system (or LMS, for short). LMS could be used by the teachers and participants with no space and time restrictions, being some form of web-based technology or software application.

The various facilities which are provided by LMS (http://elearningmethod.com) makes it easier to conduct the education and training process by means of the e-learning method. The delivery of additional materials, the process of online and offline discussions, the delivery of assignments, and the delivery of results of assignments could be conducted by virtual means. Hopefully, these facilities would become the means of making easier the process of delivering information to participants via LMS and simultaneously of the teachers and participants learning that LMS is also assumed to be a place for virtual education and training sessions.

\section{6) Facilities and Resources}

Facilities and resources become important part in the learning model which is being developed here. The participants and teachers of the programs which use the model would need laptops/personal computers that are to be used as means of interacting virtually with assistance of the Internet. The participants have been directed to have laptops and access to the Internet whether they are personal or provided by their institutions of origin.

\section{7) Evaluation}

The evaluation of learning achievement uses a formulation that consists of a) activity scores from assignments and b) competence test scores. The activity scores, which originate in the scores for assignments within the period of the e-learning process, are given $40 \%$ of weight. The competence test scores are obtained by participants' completion of comprehensive test materials at the end of the learning activities. The competence test scores obtained are given $60 \%$ of weight. Further, each participant's total achievement score is obtained from the sum between the participant's activity score and the participant's competence score.

The constraints in using the conventional learning model form the basis of making it imperative to understand that the development of information technology in the present era of globalization has entered the world of education. In the educational world, the presence of information technology could become one of the choice alternatives to take in conducting educational programs. The appearance of information technology and its possible applications lately have given birth to questions suggesting rethinking concerning the learning process which has been 
done conventionally all this time (Knapp and Glenn, 1996).

The idea is to have an education and training program having such efficiency and effectivity from the point of both its financing and the length of time it takes to hold it that it results in the production of staff with sufficient quantity and quality who are managers of financial reports through the development of a model of an education and training program. The model to be developed are based on, among others, the following factors (Phillips, 1991: 73): (1) a budget, (2) resources, (3) program objectives, (4) the length of time it takes to hold it, (5) participant competence, (6) competence in program development, (7) instructor competence, and (8) training locations.

\section{CLOSING}

The efficiency in financing in holding a conventional education and training program which is transferred into the model of a new education and training program could accelerate the availability of staff who are state finance managers and particularly functional staff for the composition of financial reports. However, the fulfillment of the required staff quantity should still be together with an education and training pattern which suits the expected quality of sumber daya manusia (or human resource) or SDM, for short, namely, being professional and accountable.

Ghazali (2006: 1-3) states that learning in the twenty-first century would greatly depend on information technology and particularly computer use. This change would directly involve the processes of teaching, learning, and education. Developments in computer and Internet technology in the educational system have improved teaching and learning phases. The learning strategies which use the computer and the Internet in education indicate considerable improvements in the aspects of education, competence, and expertise. Many studies based on the computer, multimedia, and Internet mentioned as computer-based learning leave positive impressions on the process of learning.

Therefore, shifts of information technology in the world of education finally come to the use of elearning. As for what is meant by e-learning, it refers to the system of education which uses electronic applications to support teaching-learning activities with media in the form of the Internet, computer networks, or just computers (Romi SW, 2007). Meanwhile, what is meant by distance learning is a learning process characterized as the part between participants or users and instructors or teachers where communication is weaved through television, telephone, computer, or radio facilities (Golsdstein \& Ford, 2003: 251).

The key to success in using the e-learning model is a high level of function in the interaction between the users and the instructors (Golstein \& Ford, 2003: 251). Failure in e-learning implementation is not solely due to a problem with tools, software, or infrastructure; instead, it tends to be due to a change which is felt to be too heavy a burden in the work culture and the absence of motivation for knowledge sharing. The e-learning model would become popular along with the organizational needs in the development of SDM quality. Because this model reduces training expenses, it makes an impact on the budgetting and results in that, along with an increase in SDM, there is also an increase in competence.

The use of the e-learning method being increasingly more favored by the world of education could cause positive impacts, namely, (1) it indeed turns out to be relatively more effective and efficient; (2) it saves time, expense, and energy; and (3) it encourages learners to make beneficial use of technology. Besides positive impacts, the use of this method also causes negative impacts, namely, making learners lazy, making them move increasingly farther from books, and making them become less familiar with and less respectful of their teachers because of the lack of direct communication.

Therefore, the use of the e-learning method should be re-examined to make sure whether it is actually beneficial for learners or not. Dublin in Romi SW (2007) notes that a study conducted by Forrester Group at forty large companies indicates that most of the employees (to the extent of more than $68 \%$ ) refuse to participate in the training which uses the concept of e-learning. When the elearning is made obligatory to them, up to $30 \%$ of them refuse to participate in it. Meanwhile, according to Delio in Romi SW (2007), it is indicated that of a number of people who register to teach e-learning, up to $50 \%-80 \%$ of them never continue to the end of the course.

The advantages of using the learning model which involves information technology and simultaneously makes the mastery of materials optimum through the face-to-face learning process indicate that such a class design is more efficient and effective compared to a conventional class design

(http://www.moresteam.com/blended_learning/).

The advantages are, among others, (1) it saves expenses because it lessens to the minimum face- 
to-face interaction, teachers' and students' transportation, and lesson module multiplication expenses (which could be made to undergo reduction amounting to $50 \%$ and sometimes even more); (2) graduates are more competent because more emphasis is given to practice persentage to achieve the purpose of dynamic and interactive learning; (3) there is certain flexibility for the education and training participants because elearning components possess a nature which enables the participants to start anytime anywhere convenient for them so that they would be forced to be independent and to motivate themselves to learn in accordance with their need and capability; (4) there is likewise certain flexibility for the teachers because e-learning components give the impact of making their interaction process with the participants unrestricted by space and time; and (5) consistency for organization in designing the education and training program in accordance with strategic objectives reduces to the minimum the conventional education and training expenses transferred to an effective model so that the needs of skill training are fulfilled more quickly.

\section{REFERENCE}

[1] The Act number 17 Year 2003 about State Finance

[2] The Act Number 1 Year 2004 about State Treasury

[3] Depdiknas. (2007). Kompetensi guru sesuai standar nasional pendidikan (snp). seri penelitian kebijakan. Pusat Penelitian Kebijakan dan Inovasi Pendidikan. Balitbang Depdiknas. Jakarta.

[4] Ghazali, Hassan Mohd. (2006). Kelebihan dan kelemahan penggunaan sumber dan perkhidmatan internet dalam pengajaran dan pembelajaran. Fakulti Seni dan Muzik, UPSI. http://www.scribd.com/doc/16660458/Kelebih an-dan-kelemahan-penggunaan-sumber-danperkhidmatan-internet-dalam-pengajaran-danpembelajaran download 10 Agust 2009

[5] Goldstein, Irwin L. \& Ford, J.K. (2003). Training in Organizations.Needs Assesment, Development, and Evaluation. Fourth Edition. Wadsworth Group

[6] Knapp, LR \& Allen D. Glenn. (1996). Restructuring School with Technology. Boston: Allyn \& Bacon.

[7] Noe, Raymond A. (2008). Employee Training \& Development. Forth Edition. McGraw Hill International Edition

[8] Phillips, Jack J. (1991). The handbook of training evaluation and measurement methods.
Second Edition. Publishing: Gulf Publishing Company, Houston, Texas.

[9] Romi Satrio Wahono. (2007). Sistem elearning berbasis model motivasi komunitas. Jurnal teknodik No. 21/XI/TEKNODIK/Agustus/2007, Agustus 2007 download from http://ilmukomputer.org/2009/01/10/sistemelearning-berbasis-model-motivasi-komunitas/ on 30 Mei 2009

[10] Saadé, Raaf George., \& Kira, Dennis. (2009). Computer anxiety in e-learning: the effect of computer self-efficacy Journal of Information Technology Education volume 8. 178-191. Diunduh www.jite.org/documents/vol8/p177-191/pdf tanggal 22 Juli 2ppel009

[11] Wong, Anthony Tik Tsuen. 5i: a design framework for hybrid learning. dalam Fong,Joseph. Reggie Kwan \& Fu Lee Wang. (2008). Hybrid Learning and Education: ICHL 2008.LNCS 5169,pp147-156. 